\title{
PRIMARY STRUCTURE OF THE ASPARTIC PROTEINASE A FROM SACCHAROMYCES CEREVISIAE
}

\author{
by
THOMAS DREYER, BARBARA HALKIER, IB SVENDSEN and MARTIN OTTESEN \\ Department of Chemistry, Carlsberg Laboratory, \\ Gamle Carlsbergvej 10, DK-2500 Copenhagen Valby
}

\begin{abstract}
Keywords: Proteinase A, Saccharomyces cerevisiae, Saccharomyces carlsbergensis, amino acid sequence, immunology, $\mathrm{N}$-linked carbohydrate
\end{abstract}

\begin{abstract}
Proteinase A was purified by an improved large scale procedure and split into fragments by means of trypsin, cyanogen bromide, hydroxylamine, and o-iodosobenzoic acid. On the basis of high degrees of homology with cathepsin $D$ and pepsin its amino acid sequence was determined. Proteinase $A$ contains 329 amino acid residues, and in addition $8.5 \%$ neutral sugar and $1 \%$ glucosamine, attached to asparagines in positions 67 and 267 . Proteinase A contains two disulfide bonds, as opposed to three in mammalian aspartic proteinases. Comparison with the tertiary structure of pepsin indicates, that the two catalytically essential aspartic acid residues, and the residues corresponding to their surroundings, are conserved. The sequence shows $46 \%$ identity with porcine cathepsin $D$ and $40 \%$ with porcine pepsin. An aspartic proteinase from Saccharomyces carlsbergensis had the same $\mathrm{N}$-terminal 40 amino acid sequence as proteinase $A$. Immunological cross-reactivity between proteinase $A$ and calf chymosin was demonstrated by immune blotting assay.
\end{abstract}

\section{INTRODUCTION}

The occurrence of proteolytic enzyme activity in an acid yeast lysate was recognized as early as 1889 (41), and the enzyme responsible for this activity, proteinase $\mathrm{A}$, was isolated in 1967 (19, 30). The enzyme is classified as an aspartic proteinase, due to its proteolytic activity at low pH and inhibition by 1,2-epoxy-3-(p-nitrophenoxy)propane (EPNP) and diazoacetyl-D,L-norleucine methyl ester (DAN) $(32,49)$. Proteinase $A$ is located in the lysosome-like vacuoles of the yeast, together with the serine proteases, proteinase $B$ and carboxypeptidase $Y(31)$. The three vacuolar enzymes have been implicated with unspecific proteolytic functions, e.g. protein degradation during nitrogen starvation (51). Proteinase $\mathrm{A}$ is a glycoprotein with a molecular weight of approx. 41,500, and the amino acid composition shows similarities with other aspartic proteinases: pepsin, penicillopepsin, cathep$\sin \mathrm{D}$ and chymosin (35). Cathepsin D, which is the only other intracellular aspartic proteinase that has been sequenced, exhibits structural features which are thought to be significant for processing and targeting of a lysosomal enzyme $(12,44)$. The primary structure of proteinase A may generate some insight into the corresponding processes for vacuolar enzymes $(11,26)$.

Abbreviations: DAN = diazoacetyl-norleucine methyl ester; DPCC $=$ diphenyl carbamyl chloride; EPNP: 1,2-epoxy-3-(p-nitrophenoxy) propane; FPLC $=$ fast protein liquid chromatography; HPLC $=$ high performance liquid chromatography; $\mathrm{PMSF}$ = phenyl methylsulfonyl fluoride; SDS-PAGE = sodium dodecylsulphate-polyacrylamide gel electrophoresis; TEA = triethylamine; TFA = trifluoroacetic acid. 
The present paper describes an improved purification procedure of proteinase $A$ from Saccharomyces cerevisiae, based on anion-exchange and hydrophobic-interaction chromatography, and the complete sequence of 329 amino acid residues has been determined by automated Edman degradation of fragments obtained by chemical and enzymatic cleavages. The sequence of proteinase $A$ is compared to the known primary structures of porcine cathepsin $\mathrm{D}(44)$, human renin (21), porcine pepsin (43), bovine chymosin (13) and penicillopepsin (22), with emphasis on residues corresponding to catalytically and structurally important residues in the enzymes with known three-dimensional structure.

An aspartic proteinase was isolated from Saccharomyces carlsbergensis, which had the same $\mathrm{N}$-terminal amino acid sequence as proteinase $A$, and immunological studies revealed complete cross-reactivity between these two enzymes.

\section{MATERIALS}

Baker's yeast (Saccharomyces cerevisiae) was obtained from De Danske Spritfabrikker, Denmark, and Brewer's yeast (Saccharomyces carlsbergensis) was obtained from the Carlsberg Breweries, Denmark. Sephadex G100, Sephadex G200 (superfine), Phenyl-Sepharose and a "Mono Q" anion-exchange column were obtained from Pharmacia, Sweden. Bio-Gel P4, P6 and P60 were from Bio-Rad Lab., USA and DE-52 anion-exchange cellulose from Whatmann, U.K. An affinity resin for carboxypeptidase $\mathrm{Y},((\mathrm{N}-\varepsilon$-aminocaproyl)-p-aminobenzyl) succinyl-Sepharose (CABS-Sepharose) (24) and carboxypeptidase II from malt was kindly donated by K. BREDDAM. Hog pepsin, DPCCtreated trypsin, carboxypeptidase $\mathrm{A}$ and $\mathrm{B}$, PMSF, sperm whale myoglobin, pepstatin, DAN and EPNP were purchased from Sigma, USA, and 2-vinylpyridine was from Janssen, Belgium. Extracts of calf chymosin, porcine pepsin and the aspartic proteinases from Mucor miehei, Mucor pusillus and Endothia parasitica, as well as the antisera against the first four of these enzymes, were a kind gift from Christian Hansens Laboratories, Denmark. Peroxidase conjugated goat anti-rabbit antibodies were obtained from Dako, Denmark. All other chemicals were analytical grade.

\section{METHODS}

\subsection{Isolation and characterization of aspartic proteinases from yeast \\ 3.1.1. Aspartic proteinase from Saccharomyces carlsbergensis}

An aspartic proteinase from Saccharomyces carlsbergensis was purified as earlier described (5), by a modification of MEUSSDOERFFER et al.'s procedure (35). The enzyme was stored in solution, $5 \mathrm{mg} / \mathrm{ml}$ in $0.05 \mathrm{M}$-ammonium acetate pH 5.0, at $-23{ }^{\circ} \mathrm{C}$.

\subsubsection{Proteinase A from Saccharomyces cerevisiae}

Proteinase A from Saccharomyces cerevisiae was obtained by a simplified procedure, omitting the ammonium sulfate precipitation and addition of mercuric chloride in the earlier procedure (5). The initial steps followed the procedure for isolating carboxypeptidase $Y$ (CPD-Y) (24): $15 \mathrm{~kg}$ of baker's yeast was crushed and mixed with 1.51 ether, which liquefied the yeast, 151 water was added, $\mathrm{pH}$ was adjusted to 7.4 , and cell autolysis was allowed to proceed for 21 hours at $20^{\circ} \mathrm{C}$. After centrifugation at $7500 \times \mathrm{g}$ for $30 \mathrm{~min}, \mathrm{pH}$ of the supernatant was adjusted to 5.0 with $30 \%(\mathrm{v} / \mathrm{v})$ acetic acid, and the solution was kept at $30^{\circ} \mathrm{C}$ for 20 hours with stirring. This treatment activated proteinase $\mathrm{A}$ and after clarification by centrifugation, CPD-Y was removed from the solution by passing it through a $20 \mathrm{ml}$ CABS-Sepharose column, equilibrated with $10 \mathrm{~mm}$-sodium acetate, $\mathrm{pH}$ 5.0. This and all subsequent steps were performed at $4{ }^{\circ} \mathrm{C}$. The run-off $(25 \mathrm{l})$ was dialysed against $10 \mathrm{~mm}$-sodium acetate, $\mathrm{pH} 5.0$, and concentrated to 101 in a Millipore Pellicon Ultrafiltration system, with a PTGC membrane with cut-off level 10,000 dalton. Two liters of anion-exchange cellulose DE 52, was added and after stirring for $20 \mathrm{~min}$ the gel was transferred to a column $(10 \times 25 \mathrm{~cm})$, and washed with 101 of 10 mM-sodium acetate pH 5.0. Enzymatic activity was eluted in one step with $0.3 \mathrm{M}-\mathrm{KCl}$ in the 
same buffer. Fractions containing enzymes were diaconcentrated to $1250 \mathrm{ml}$ against $10 \mathrm{mM}$-sodium acetate, $\mathrm{pH} 5.0$, and applied to a second DE 52 column $(10 \times 12.5 \mathrm{~cm})$, equilibrated with the same buffer. The column was eluted with a 101 linear gradient from $0-0.3 \mathrm{M}-\mathrm{KCl}$ in the buffer, flow $400 \mathrm{ml} / \mathrm{h}$. Fractions containing acid proteolytic activity were pooled and applied.at $1000 \mathrm{ml} / \mathrm{h}$ directly to a Phenyl-Sepharose column $(10 \times 12.5 \mathrm{~cm})$, which had been equilibrated with $50 \mathrm{mM}$-sodium acetate, $\mathrm{pH}$ 5.0. The gel was washed with 51 of $50 \mathrm{~mm}$-sodium acetate, $\mathrm{pH}$ 5.0 , and eluted with a 31 linear gradient from $0-90 \%(v / v)$ ethylene glycol in the same buffer, flow $200 \mathrm{ml} / \mathrm{h}$. Fractions corresponding to the UV-absorbing peak eluted with $85 \%$ (v/v) ethylene glycol were pooled and diaconcentrated against $10 \mathrm{mM}$-sodium acetate, $\mathrm{pH} 5.0$, to $50 \mathrm{ml}$ on a high pressure Amicon cell with a YM 10 membrane. Finally the concentrate was applied to a Sephadex G100 column $(2.5 \times 90 \mathrm{~cm})$ in the same buffer, $9 \mathrm{ml} / \mathrm{h}$. Fractions with acid proteolytic activity were pooled and concentrated before storage in solution at $-18{ }^{\circ} \mathrm{C}$.

\subsubsection{Molecular weight and isoelectric point determination}

The molecular weights of proteinase $A$ and the Saccharomyces carlsbergensis proteinase were estimated by gel filtration on a Sephadex G 200 (superfine) column $(1.6 \times 90 \mathrm{~cm})$ in $0.1 \mathrm{M}$-ammonium acetate $\mathrm{pH} 5.5$, and by electrophoresis in a $10 \%(\mathrm{w} / \mathrm{v})$ SDS-polyacrylamide gel (29).

Isoelectric focusing was performed in a 0.5 $\mathrm{mm} 5 \%(\mathrm{w} / \mathrm{v})$ polyacrylamide slab gel containing a pH gradient from $\mathrm{pH} 2.5$ to 5.0 created by ampholytes. Polymerization of the acrylamide in this $\mathrm{pH}$ interval was made possible by the addition of $0.3 \%(\mathrm{w} / \mathrm{v})$ silver nitrate. Marker proteins were used to standardize the methods.

\subsubsection{Amino acid analysis}

Samples were hydrolyzed with $6 \mathrm{~N}-\mathrm{HCl}$ at 110 ${ }^{\circ} \mathrm{C}$ in evacuated tubes for 24 hours, in some cases also for 48 and 72 hours. Hydrolysates were analyzed by a Durrum D500 amino acid analyzer. Tryptophan was determined by the meth- od of EDELHOCH (10) and halfcystine as cysteic acid after performic acid oxidation according to HIRS (20).

\subsubsection{Carbohydrate analysis}

An estimation of the total content of neutral carbohydrate in proteinase A and the Saccharomyces carlsbergensis proteinase was obtained by means of the phenol-sulphuric acid procedure (7), using mannose as standard. Glucosamine was determined on the Durrum amino acid analyzer after hydrolysis in $6 \mathrm{~N}$-hydrochloric acid at $110^{\circ} \mathrm{C}$ in vacuo for 2,4 and 6 hours, using glucosamine as standard.

\subsubsection{Activity measurements}

The proteolytic activities of proteinase $A$ and the aspartic proteinase from Saccharomyces carlsbergensis were measured with acid denatured tritium-labeled bovine hemoglobin, as described by DREYER et al. (5). A $125 \mu$ l sample, diluted in $0.1 \mathrm{M}$-glycine- $\mathrm{HCl}$ buffer, $\mathrm{pH} 3.5,37$ ${ }^{\circ} \mathrm{C}$, was added to $125 \mu 12 \%(\mathrm{w} / \mathrm{v})$ tritium labelled hemoglobin in this buffer. After $30 \mathrm{~min}$ at $37^{\circ} \mathrm{C}$, $250 \mu \mathrm{l} 10 \%(\mathrm{v} / \mathrm{v})$ trichloroacetic acid, $4{ }^{\circ} \mathrm{C}$, was added. The mixture was kept at $4{ }^{\circ} \mathrm{C}$ for $45 \mathrm{~min}$ to complete precipitation. After centrifugation $400 \mu \mathrm{l}$ supernatant was mixed with $5 \mathrm{ml}$ Dimilume 30 and counted in a liquid scintillation counter. Since different batches of hemoglobin showed variable digestability a sample of purified homogenous proteinase $\mathrm{A}$ was used to standardize each assay, and the activity is expressed as $\mu \mathrm{g}$ proteinase $\mathrm{A}$.

\subsubsection{Immunological procedures}

Rabbit antiserum raised against purified proteinase A from S. cerevisiae, was produced and isolated as described by HARBOE and INGILD (17). The antiserum was specific for proteinase $A$, as judged from the occurrence of a single immune stained band on a nitrocellulose filter with yeast extract, electroblotted from SDSPAGE. This antiserum was used to examine proteinase A and the Saccharomyces carlsbergensis proteinase for immunological homology by tandem crossed immunoelectrophoresis (28), 
in $1 \%(w / v)$ agarose gel in Tris-veronal buffer $\mathrm{pH}$ 8.6, containing antiserum, $0.6 \mu \mathrm{l}$ per $\mathrm{cm}^{2}$. Electrophoretic blotting and immune assay was performed by means of SDS-PAGE according to LAEMMLI (29). Immediately after completion of the electrophoretic run, the polypeptides were transferred to a nitrocellulose filter, as described by TowBIN et al. (50). The nitrocellulose filter was cut into strips, and incubated with antibodies at pH 10.2, according to BJERRUM et al. (2). Bands were visualized using peroxidase conjugated goat anti-rabbit antibodies and 3-amino9-ethylcarbazole as described by GRAHAM et al. (15).

\subsection{Amino acid sequence}

\subsubsection{HPLC-separation of peptides}

Peptides from enzymatic and chemical cleavages of proteinase A were purified by reversephase HPLC applying a $7.8 \times 300 \mathrm{~mm}$ steel column with Synchropak RP-P wide pore C-18 material, packed according to the dynamic slurry packing technique described by KELLER et al. (27). $2-10 \mathrm{mg}$ peptide mixtures were separated employing Waters HPLC equipment: two Model 600A pumps, a WISP sample injector, a Model 660 solvent programmer, a Model 450 var. wavelength UV detector and a Model 420 fluorescence detector together with an LKB 2210 2-channel recorder and an LKB 2211 "Superrac" fraction collector. Gradient elution was achieved with continuously increasing concentrations of acetonitril in $0.05 \%(\mathrm{v} / \mathrm{v}) \mathrm{TFA}$, $0.05 \%(v / v)$ TEA. The eluent was monitored at $220 \mathrm{~nm}$, supplemented with fluorescence detection at $375 \mathrm{~nm}$ after excitation at $280 \mathrm{~nm}$, to detect tryptophan containing peptides. Peaks containing more than one peptide were rechromatographed either in the same system with a flatter gradient, by using a Novapak column with gradients of acetonitril in $0.1 \%$ TFA, or by employing the Pharmacia FPLC system with Mono $Q$ anion-exchanger and 20-30 min gradients from $0.05-0.4 \mathrm{M}$-ammonium bicarbonate, $\mathrm{pH} 7.9$, flow $1 \mathrm{ml} / \mathrm{min}$.

\subsubsection{Reduction and 2-pyridylethylation}

Proteinase A, $200 \mathrm{mg}$ in $10 \mathrm{ml} 7 \mathrm{M}$-guanidinium-HCl, $0.2 \mathrm{M}$-Tris, pH 7.6, 5 mM-EDTA, was flushed with nitrogen and reduced by adding $2 \mathrm{ml} 0.23 \mathrm{M}$-dithiothreitol. After $30 \mathrm{~min}$ the cysteine residues were alkylated with $3 \times 70 \mu \mathrm{l}$ 2-vinylpyridine (14). After 2 hours the $\mathrm{pH}$ of the solution was adjusted to 4.0 with acetic acid, and it was dialysed against $2 \%$ acetic acid with $5 \%$ ethanol. A precipitate was formed, and the suspension was lyophilized.

\subsubsection{Chemical cleavages}

Cyanogen bromide cleavages of reduced and alkylated proteinase $\mathrm{A}$, or tryptic peptides, were performed in $70 \%(\mathrm{v} / \mathrm{v})$ trifluoroacetic acid at 21 ${ }^{\circ} \mathrm{C}$ for 20 hours with a 250 fold molar excess of CNBrover methionine. $2 \mathrm{M}$-hydroxylamine was used to cleave Asn-Gly bonds (3) in $6 \mathrm{M}$-guanidinium hydrochloride, adjusted and kept at $\mathrm{pH}$ 9.0 with $\mathrm{LiOH}$, during 4 hours reaction at $45^{\circ} \mathrm{C}$. After desalting on Bio-Gel P4 in $0.05 \mathrm{M}$-ammonium bicarbonate the fragments were separated by reverse-phase HPLC using Synchropak RP-P and gradients of acetonitril in $0.1 \%(\mathrm{v} / \mathrm{v})$ TFA.

Cleavage after tryptophans was performed using o-iodosobenzoic acid (33), $20 \mathrm{mg} / \mathrm{ml}$, and tyramine hydrochloride, $4 \mathrm{mg} / \mathrm{ml}$, in $4 \mathrm{M}$-guanidinium hydrochloride and $80 \%(\mathrm{v} / \mathrm{v})$ acetic acid. After reaction of the enzyme, $3.5 \mathrm{mg} / \mathrm{ml}$, with this mixture at $21^{\circ} \mathrm{C}$ for 22 hours in the dark, the solution was desalted on Bio-Gel P6 in 30\% (v/v) acetic acid, and the fragments were separated on Bio-Gel P60 $(1 \times 90 \mathrm{~cm})$ in $0.2 \mathrm{M}$-ammonium bicarbonate.

\subsubsection{C-terminal determination}

The C-terminal sequence was established after addition of carboxypeptidase $A(3 \mu \mathrm{M})$ to proteinase $\mathrm{A}(500 \mu \mathrm{M})$ in $0.05 \mathrm{M}-\mathrm{N}$-ethylmorpholine buffer, $\mathrm{pH}$ 8.5. Aliquots were withdrawn after 2, 6, 20 and $60 \mathrm{~min}, 5 \mu \mathrm{l} 1 \mathrm{M}-\mathrm{HCl}$ was added to each aliquot to stop the hydrolysis. Carboxypeptidase $B$ was then added $(3 \mu \mathrm{M})$ and aliquots withdrawn after further $2,6,20$ and $60 \mathrm{~min}$ incubation time for inactivation with $5 \mu \mathrm{l} 1$ $\mathrm{M}-\mathrm{HCl}$. Liberated amino acids were determined in samples applied directly to the amino acid analyzer.

A tryptic peptide T5 $(410 \mu \mathrm{M})$ was digested with malt carboxypeptidase II $(1.6 \mu \mathrm{M})$ in 0.05 
$\mathrm{M}$-sodium acetate $\mathrm{pH} 4.0$, and $30 \mu \mathrm{l}$ aliquots were withdrawn after 5,25 and $120 \mathrm{~min}$. To each of these $5 \mu 11 \mathrm{M}-\mathrm{HCl}$ was added before direct injection in the amino acid analyzer.

\subsubsection{Trypsin digestions}

Two procedures were used. In the first $100 \mathrm{mg}$ reduced and 2-pyridylethylated proteinase $A$ was dissolved in $20 \mathrm{ml} 0.1 \mathrm{M}$-sodium bicarbonate, $\mathrm{pH} 8.0$, and digested with $1 \mathrm{mg}$ DPCCtrypsin at $37{ }^{\circ} \mathrm{C}$ for 3 hours. In the second the buffer used was $0.02 \mathrm{M}$-N-ethylmorpholine-acetic acid, $\mathrm{pH}$ 8.0, DPCC-trypsin was added in the ratio $1: 50$ and digestion proceeded for $30 \mathrm{~min}$ at $12{ }^{\circ} \mathrm{C}(16)$. In both cases the reaction was terminated by the addition of PMSF in 50\% excess.

Modification of the primary amino groups of lysine residues in reduced and alkylated proteinase $\mathrm{A}$ with citraconic anhydride was performed according to the procedure of DIXON and Perham (4), and the subsequent tryptic digestion took place in $0.1 \mathrm{M}$-sodium bicarbonate, $\mathrm{pH}$ $8.0,37{ }^{\circ} \mathrm{C}$ for 3 hours with an enzyme to substrate ratio of 1:100.

\subsubsection{Isolation of tryptic peptides}

Peptides from tryptic digestion of reduced, 2-pyridylethylated proteinase $A$ were separated on a column $(2.6 \times 90 \mathrm{~cm})$ of Bio-Gel P60 in 0.2 M-sodium bicarbonate $\mathrm{pH}$ 7.6. Four resolved peptide pools were obtained, three of which were largely soluble after lyophilization in $0.1 \%(\mathrm{v} / \mathrm{v})$ TFA, $5 \%(\mathrm{v} / \mathrm{v})$ acetic acid, whereas a small high molecular weight pool was insoluble even in $30 \%(\mathrm{v} / \mathrm{v})$ acetic acid. Subsequent isolation of peptides from the three pools were performed with semi-preparative reverse-phase HPLC (see section 3.2.1). All peptides were lyophilized immediately after the chromatographic runs.

\subsubsection{Sequencing}

Amino acid sequences were determined either with a Beckman $890 \mathrm{C}$ spinning-cup sequencer, $(9,25)$, or with an Applied Biosystems gas phase sequencer Model $470 \mathrm{~A}$, using the programme provided by the company. Phenylthiohyd- antoins were identified by reverse-phase HPLC, as described by SVENDSEN et al. (48).

\section{RESULTS}

\subsection{Isolation of proteinase $A$ from Saccharomyces cerevisiae}

The purification procedure outlined in section 3.1.2, is a simplification and improvement of the purification procedure previously used for the aspartic proteinase from Saccharomyces carlsbergensis (5). Ammonium sulfate precipitation is replaced by a diafiltration step after the ether plasmolysis. Hydrophobic-interaction chromatography preceeds anion-exchange in the earlier procedure, while the order is reversed in the present procedure, to take advantage of the higher binding capacity of the DE cellulose.

The purification procedure of proteinase $A$ includes an activation step where the specific proteinase $\mathrm{A}$ inhibitor $\mathrm{I}_{3}^{\mathrm{A}}$ is digested by other proteolytic enzymes in the yeast (40). In order to obtain high yields, it is important to separate proteinase A from these other proteolytic enzymes immediately after the activation. Carboxypeptidase $\mathrm{Y}$ is removed with the CABS-Sepharose, and the second anion-exchange on DE 52 , separates proteinase A from an earlier eluting peak containing proteinase $\mathrm{B}$, as judged by the ability to release a $520 \mathrm{~nm}$ absorbing trichloroacetic acid soluble dye from the substrate azocoll at pH 7.0 (39). Hydrophobic-interaction chromatography on Phenyl-Sepharose removes most of a dark brown pigment which does not bind to the column under the conditions described. The final gel filtration isolates proteinase A from a high molecular weight brown contaminant, which is presumably an aggregate of proteinase $A$ and pigments, as judged from the amino acid composition, which is similar to proteinase A. Lyophilization of proteinase $A$ is avoided, as this frequently leads to inactivation of the enzyme. The purification procedure is summarized in Table $\mathrm{I}$.

The stability of proteinase $A$ in frozen solution at $5-25 \mathrm{mg} / \mathrm{ml}$ is high, the specific activity remains almost constant for 6 months.

During later purifications, run-offs from an affinity column used for commercial production of carboxypeptidase $\mathrm{Y}$, were kindly donated by 
Table I. Purification of proteinase A from Saccharomyces cerevisiae

\begin{tabular}{lrrrr}
\hline & $\begin{array}{l}\text { Volume } \\
\mathrm{ml}\end{array}$ & $\begin{array}{l}\text { Protein } \\
\mathrm{mg}\end{array}$ & $\begin{array}{l}\text { Spec. act. } \\
\mu \mathrm{g} \text { prot.A/ } \\
\text { mg protein }\end{array}$ & $\begin{array}{l}\text { Yield } \\
\%\end{array}$ \\
\hline Activated extract, $\mathrm{pH} 5.0$ & 25,000 & 307,500 & 16 & 100 \\
Run-off from CABS-Sepharose & 25,000 & 307,500 & 16 & 100 \\
After ultrafiltration & 10,000 & 84,300 & 19 & 30 \\
DE 52 anion-exchange, one step elution & 1,250 & 9,000 & 86 & 14 \\
DE 52 anion-exchange, gradient elution & 2,100 & 4,120 & 150 & 11 \\
Phenyl-Sepharose & 50 & 680 & 691 & 9 \\
Sephadex G100 & 41 & 430 & 1000 & 8 \\
\hline
\end{tabular}

Pharmacia, Denmark. This run-off was equivalent to the above described in all subsequent purification steps, and resulted in a high yield of pure proteinase $\mathrm{A}$.

\subsection{Isolation of aspartic proteinase from $S$. carlsbergensis}

The amount of carlsbergensis enzyme isolated from each $\mathrm{kg}$ of yeast was approx. half of the amount of proteinase A isolated from Saccharomyces cerevisiae. This was partially due to a very high content of dark pigments that bound irreversibly to chromatographic columns and filters leading to reduced capacity, prolonged separation times, and increased losses, and partially to a lower content of aspartic proteinase in the $\mathbf{S}$. carlsbergensis. The specific activity of the carlsbergensis enzyme, based on amino acid analysis, was approx. $20 \%$ lower than the activity of proteinase A, probably because the preparation contained some denatured or damaged enzyme.

\subsection{Physical and chemical properties}

SDS-PAGE indicated molecular weights of proteinase $A$ and the aspartic proteinase from Saccharomyces carlsbergensis of 41,000 and 43,000 , respectively, while gel filtration resulted in 43,000 and 45,000 , respectively. The content of neutral carbohydrate was estimated to $10 \%$ $(w / w)$ in the cerevisiae enzyme and $8.5 \%(w / w)$ in the carlsbergensis enzyme while glucosamine contents of $1.0 \%$ and $1.7 \%$, respectively, were found after acid hydrolysis. These values for proteinase $A$ are in close agreement with those reported for this enzyme by MEUSSDOERFFER et al. (35).

In the isoelectric focusing gel, proteinase A and the aspartic proteinase from Saccharomyces carlsbergensis both displayed 3-4 distinct bands in a narrow range between $\mathrm{pH} 4.0$ and $\mathrm{pH} \mathrm{4.1}$, which is approx. $0.4 \mathrm{pH}$ units lower than the earlier reported isoelectric point of proteinase $\mathrm{A}$ (35).

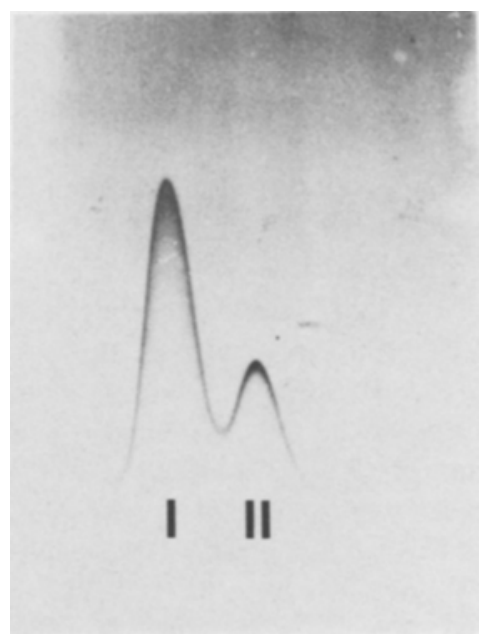

Figure 1. Tandem crossed immunoelectrophoresis of proteinase A from Saccharomyces cerevisiae and aspartic proteinase from Saccharomyces carlsbergensis, using antiserum against proteinase $\mathrm{A}$. Well I contained $23 \mu \mathrm{g}$ proteinase A from Saccharomyces cerevisiae and Well II contained 7.5 $\mu$ g Saccharomyces carlsbergensis proteinase. 


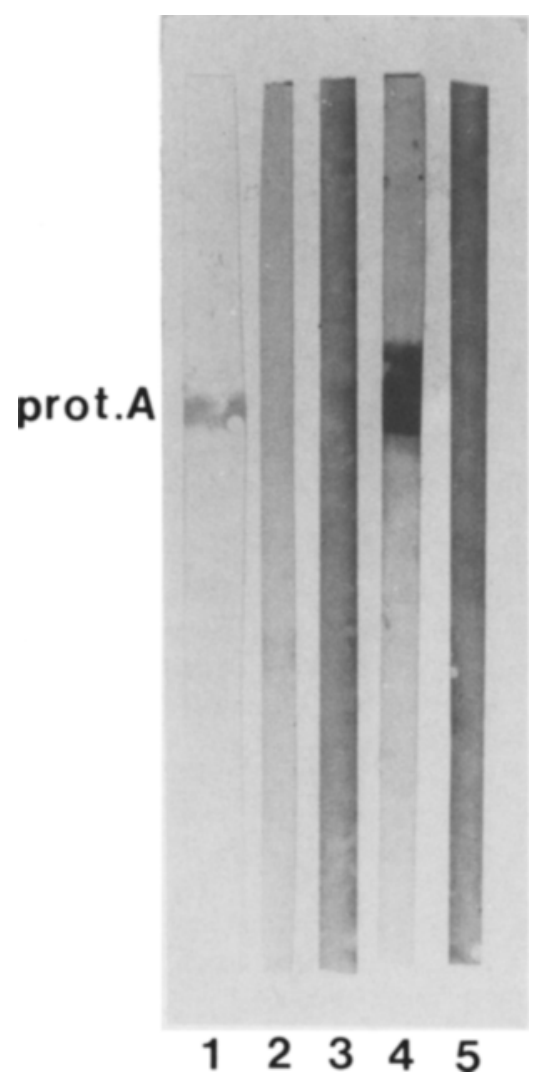

Figure 2. Cross-reactivity between proteinase $A$ and rabbit antisera raised against other aspartic proteinases. 1: Amidoblack staining of proteinase A on nitrocellulose filter. 2: Immuno-staining of proteinase A after incubation with antiserum against the aspartic proteinases from Mucor miehei (2) and Mucor pusillus (3), bovine chymosin (4) and porcine pepsin (5).

The amino acid compositions of proteinase $A$ (not shown) was similar to the earlier reported composition (35). The proteolytic activity of proteinase A towards acid denatured hemoglobin was inhibited by DAN, EPNP, pepstatin and $I_{3} \hat{3}$, as previously observed (35). The aspartic proteinase from Saccharomyces carlsbergensis revealed similar behaviour in inhibition assays (results not shown). The pH optimum towards acid denatured hemoglobin was 3.2 for both enzymes, and they retained more than $80 \%$ of the initial activity after incubation for 48 hours at $\mathrm{pH}$ between 3.5 and 7.0 (results not shown).

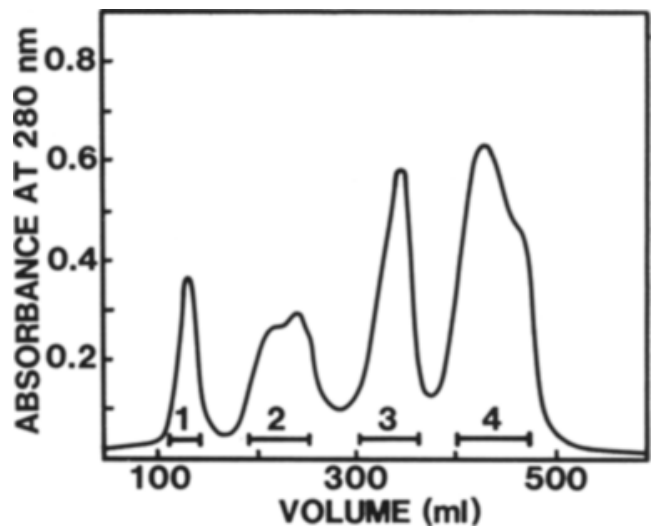

Figure 3. Elution profile of tryptic digest of reduced and alkylated proteinase $\mathrm{A}\left(37^{\circ} \mathrm{C}, 3\right.$ hours) on Bio Gel P60 $(2.5 \times 90 \mathrm{~cm})$ in $0.2 \mathrm{M}$-sodium bicarbonate. Flow 9 $\mathrm{ml} / \mathrm{h}$.

\subsection{Immunological properties}

Proteinase A and the Saccharomyces carlsbergensis proteinase formed, in tandem crossed immunoelectrophoresis with the proteinase A antiserum, immune precipitates which completely fused, and thus suggested identity between the two enzymes (see Figure 1).

The immunological relationship between proteinase $A$ and other aspartic proteinases was investigated by immune blotting. Proteinase A was allowed to react with antisera against calf chymosin, porcine pepsin and aspartic proteinases from Mucor miehei and Mucor pusillus. Only the anti-chymosin antiserum crossreacted, indicating common antigenic determinants on proteinase $\mathrm{A}$ and chymosin (see Figure 2). However, antiserum raised against proteinase A did not cross-react with calf chymosin, porcine pepsin or the aspartic proteinases from Mucor miehei, Mucor pusillus and Endothia parasitica.

\subsection{Amino acid sequences}

Reduced and vinylpyridinylated proteinase $A$ was sequenced through residue 44 on the Beckman spinning-cup sequencer, with the sequence shown in Figure 6. The N-terminal sequence of aspartic proteinase from Saccharomyces carls- 

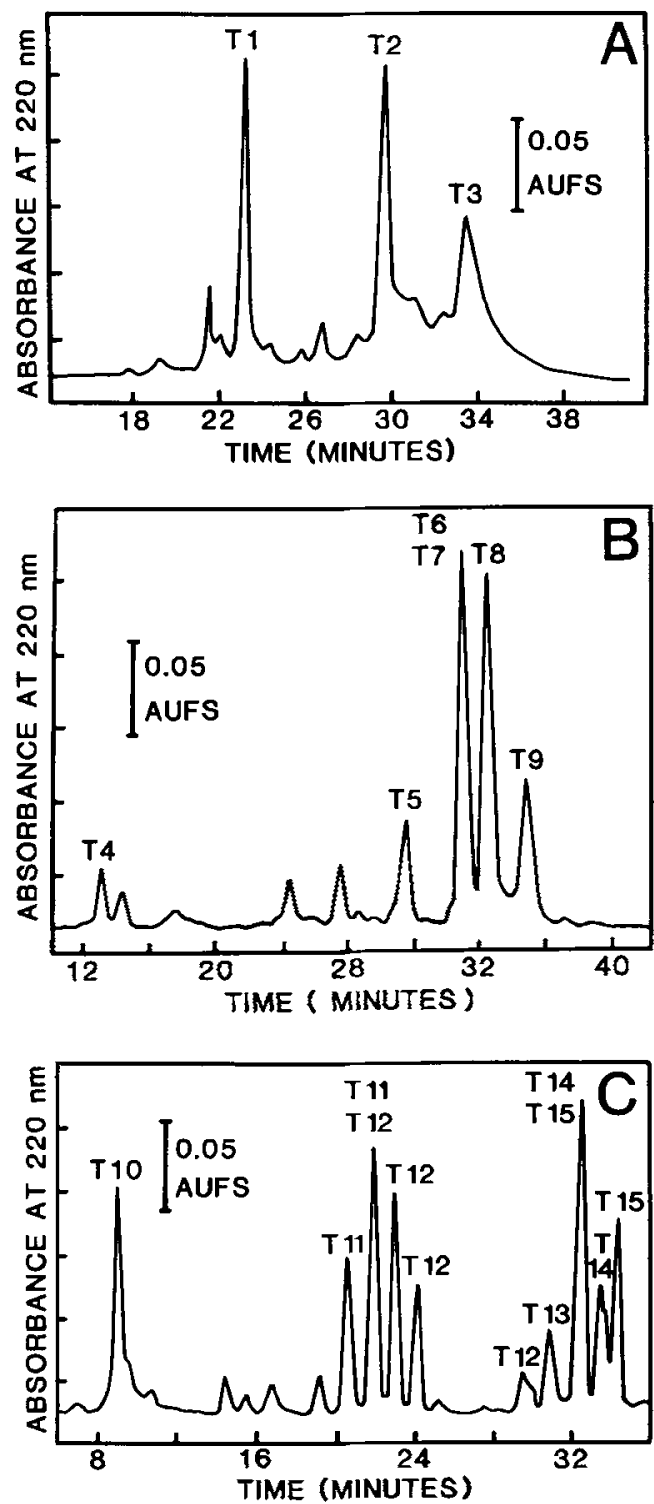

Figure 4. Fractionation of peptide pools $2-4$ on a reverse-phase widepore HPLC column, Synchropak RP-P $(7.8 \times 300 \mathrm{~mm})$. The gradients were acetonitril, A: $15 \%-60 \%(\mathrm{v} / \mathrm{v}), \mathrm{B}: 10 \%-40 \%(\mathrm{v} / \mathrm{v})$ and C: $5 \%-40 \%(\mathrm{v} / \mathrm{v})$ in $0.05 \%(v / v)$ TFA plus $0.05 \%(v / v)$ TEA. The flow rate was $4 \mathrm{ml} / \mathrm{min}$, and the eluent was monitored at 220 nm.

bergensis from residue 1 to residue 40, was identical to the sequence of proteinase $A$.

Digestion of reduced and alkylated proteinase A with carboxypeptidase $A$ and carboxypeptid-

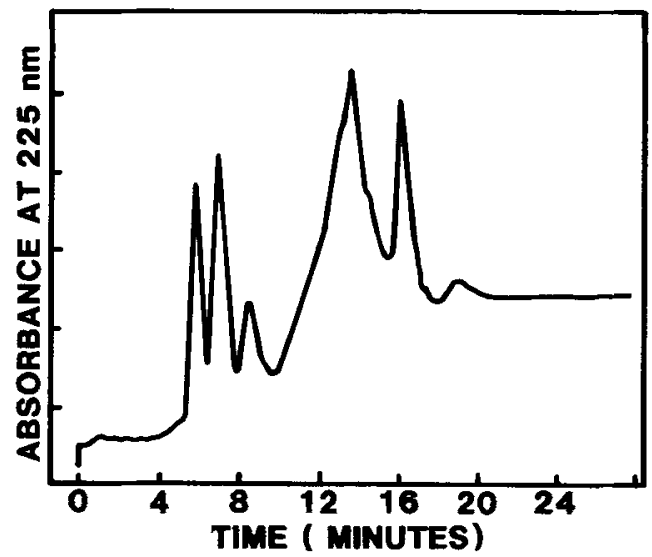

Figure 5. Rechromatography of the first eluting peak in Figure 4A, on a Mono $Q$ anion-exchange column. The gradient was ammonium bicarbonate, $0.05 \mathrm{M}-0.40 \mathrm{M}$, in $20 \mathrm{~min}$, flow rate $1 \mathrm{ml} / \mathrm{min}$. The first three peaks had identical amino acid composition, corresponding to peptide $T l$, and they all contained carbohydrate.

ase $B$, suggested the same $C$-terminal sequence, -Ala-Lys-Ala-Ile-OH, as in chymosin (13) (see Figure 7).

Proteinase A contains 2 methionines, which should give 3 peptides after cyanogen bromide cleavage. However, the reaction mixture was partially insoluble, and only 2 fragments were isolated: One was the $\mathrm{N}$-terminal fragment, and the other a fragment, $\mathrm{CB} 2$, of which 27 residues were sequenced, see Figure 6. Gel filtration of fragments from o-iodosobenzoic acid cleavage of proteinase A yielded a complex pool of unresolved high molecular weight peptides, and a low molecular weight pool, from which fragment IBA1 was sequenced.

After tryptic digestion and gel filtration the chromatogram shown in Figure 3 was obtained. 3 peptide pools, 2, 3 and 4 were soluble in $0.1 \%$ (v/v) TFA, 5\% (v/v) acetic acid after lyophilization, and further separated by reverse-phase HPLC. Figure 4A shows the elution profile of peptide pool 2, in which the large fragments $T 1$, $T 2$ and $T 3$ were separated. Since peptide $T 11$ was poorly soluble at acid $\mathrm{pH}$, it was dissolved in 20 mM-ammonium bicarbonate, $\mathrm{pH} 7.8$, and purified by anion-exchange on a Mono $Q$ column as shown in Figure 5. From peptide pool 3 reverse-phase HPLC separated tryptic peptides 
T4-T9 (Figure 4B), of which T4, T7 and T9 needed no further purification before sequencing. T5, T6 and T8 had to be rechromatographed as described in section 3.2.1. Peptide pool 4 was separated into the smaller tryptic peptides $\mathrm{T} 10$ T15 (Figure 4C).

Using this fractionation scheme the two digestion procedures (section 3.2.5) gave different yields of the tryptic peptides: $\mathrm{T} 1, \mathrm{~T} 7$ and $\mathrm{T} 10$ were preferentially obtained from $30 \mathrm{~min}, 12^{\circ} \mathrm{C}$ digestion, while $\mathrm{T} 5, \mathrm{~T} 6$ and $\mathrm{T} 8$ were obtained in higher yields from the 3 hours, $37^{\circ} \mathrm{C}$ digestion.

The reaction mixture after tryptic digestion of citraconylated proteinase A was insoluble in 0.2 $M$-sodium bicarbonate, but partially soluble in $30 \%(\mathrm{v} / \mathrm{v})$ acetic acid. Gel filtration on Sephadex $\mathrm{G} 100(1.5 \times 100 \mathrm{~cm})$ led to isolation of three peptides TC1 (identical to T3), TC2 (N-terminus equal to T13) and TC3.

The tryptic peptide $\mathrm{T} 1$ was glycosylated in position 2, as judged by carbohydrate determination and the absence of detectable PTH amino acid after Edman degradation. An asparagine placed in this position is justified from the amino acid composition of $\mathrm{T} 1$, and the presence of a threonine in position 4. T3 contained asparagine linked carbohydrate in position 14 , as judged by the same criteria. T4 had the $\mathrm{N}$-terminal sequence Asp-Thr-Glu-Asn- and a total of 17 residues, but the amount of released amino acid was abruptly reduced after step 3, with only traces of Asn in step 4, which indicated an Asn-Gly peptide bond. Hence, the peptide was treated with hydroxylamine, and this yielded the peptide NGT4, sequencing of which completed T4. The four C-terminal residues of T5 were -Ala-Phe-Gly-Lys, according to the digestion with carboxypeptidase II from malt, which successively released Lys, Gly, Phe, Ala, Phe and Thr. T6 - T10 were sequenced to the C-terminal basic residues. T11 was a tryptic fragment identical with position $2-3$ in TC3, from citraconylated proteinase $\mathrm{A}$. $\mathrm{T} 13$ and $\mathrm{TC} 2$ had the same N-terminal sequences, and the arginine prior to the $\mathrm{N}$-terminal phenylalanine was inferred from the tryptic cleavage, also when lysines were blocked by citraconic anhydride.

Sequences of the fragments accounted for 327 residues, and overlap of $\mathrm{T} 15$ with the $\mathrm{C}$-terminal sequence -Ala-Lys-Ala-Ile establishes a total of
329 residues. The $\mathrm{N}$-terminal sequence of proteinase $A$ linked residues 1 to 56 (T3 and T7), while cyanogen bromide fragment $\mathrm{CB} 2$, o-iodosobenzoic acid fragment IBA1 and the tryptic fragment of citraconylated proteinase A, TC3, linked residues 179-310 (T14, IBA1, TC3, T2, CB2, T12, and T3).

The assembly of the tryptic fragments, a cyanogen bromide peptide and an o-iodosobenzoic acid peptide shown in Figure 6, was based on sequence homologies of 8 tryptic peptides, 10 to 33 residues in length, with porcine cathepsin $D(44)$ and porcine pepsin (43).

While the present sequence determination was near completion, we learned from E.W. JONES and T.H. STEVENS (personal communications), that two groups, independently, had isolated and sequenced two genes from Saccharomyces cerevisiae, coding for a protein, which presumably was an aspartic proteinase $(46,52)$. Comparison of the amino acid sequences derived from these gene sequences with the present chemically determined proteinase A sequence, revealed identity.

\section{DISCUSSION}

The proteinases isolated from Saccharomyces cerevisiae and Saccharomyces carlsbergensis exhibited optimum $\mathrm{pH}$, stability and physical properties similar to the previousily described proteinase A from baker's yeast $(19,30,35)$. The inhibition by EPNP, DAN and pepstatin confirm that the two proteinases are aspartic proteinases, with a catalytical apparatus consisting of two aspartic acid residues.

The primary structure of proteinase A from Saccharomyces cerevisiae, in Figure 6, consists of 329 residues with a molecular weight of 35,770 , calculated from the amino acid composition. When the carbohydrate content of $10 \%$ is taken into account, this agrees reasonably well with the molecular weight estimate of 41,000 43,000 by gel chromatography and SDS-PAGE.

The primary structure of proteinase $A$ is, in Figure 7, compared with the primary structures of porcine cathepsin $D$, human renin, porcine pepsin, bovine chymosin and penicillopepsin. The amino acid sequences are aligned to maximize sequence homologies, using the number- 

N-terminal

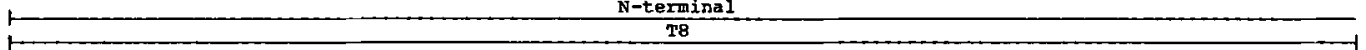

30

40

50

Val-Ile-Leu-Asp-Thr-GIy-Ser-Ser-Asn-Leu-Trp-Val-Pro-Ser-Asn-Glu-CYs-Gly-Ser-Leu-Ala-Cys-Phe-Leu-His-Ser-Lys-Tyr-AspN-terminal T10

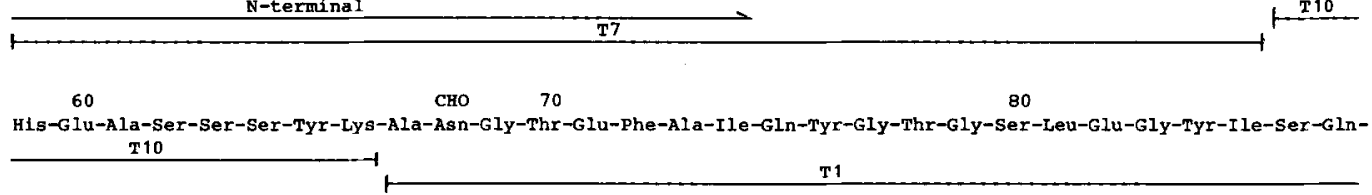

90 100

110

Asp-Thr-Leu-Ser-Ile-Gly-Asp-Leu-Thr-Ile-Pro-Lys-GIn-Asp-Phe-Ala-Glu-Ala-Thr-Ser-Glu-Pro-Gly-Leu-Thr-Phe-Ala-Phe-GlyTt TS

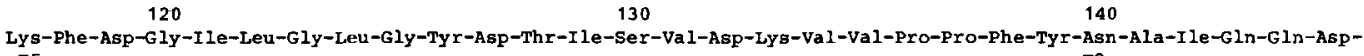
$\stackrel{\mathrm{T} 5}{-1}$ T6.....................

(1)

150

160

170

Leu-Leu-Asp-Glu-Lys-Arg-Phe-Ala-Phe-Tyr-Leu-Gly-Asp-Thr-Ser-Lys-Asp-Thr-Glu-Asn-Gly-Gly-Glu-Ala-Thr-Phe-GlY-Gly-IIeT9 $\stackrel{T 13}{\text { TC2 }}$

$180 \quad 190 \quad 200$

Asp-Glu-Ser-LYs-Phe-Lys-G lY-Asp-Ile-Thr-Trp-Leu-Pro-Val-Arg-Arg-LYs-Ala-Tyr-Txp-GIu-Val-Iys-Phe-Glu-GlY-Ile-GIy-Leu-

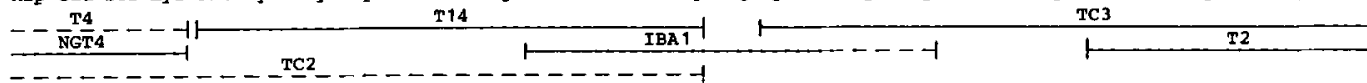

210

220 230

GlY-Asp-Glu-Tyr-Ala-Glu-Leu-Glu-Ser-His-Gly-Ala-Ala-Ile-Asp-Thr-Gly-Thr-Ser-Leu-Ile-Thr-Leu-Pro-Ser-Gly-Leu-Ala-Glu 240

Met-Ile-Asn-Ala-GIu-I le-Gly-Ala-Lys-Lys-Gly-Trp-Thr-Gly-Gln-Tyr-Thr-Leu-Asp-Cys-Asn-Thr-Arg-Asp-Asn-Leu-Pro-Asp-Leu-

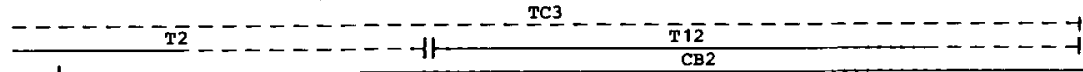

T3 TC1

$1+\operatorname{ce} 2 \quad 41 \ldots$

СHо

270

280

290

Ile-Phe-Asn-Phe-Asn-Gly-Tyr-Asn-Phe-Thr-Ile-Gly-Pro-TYr-Asp-Tyr-Thr-Leu-Glu-Val-Ser-Gly-Ser-Cys-Ile-Ser-Ala-Ile-Thr-

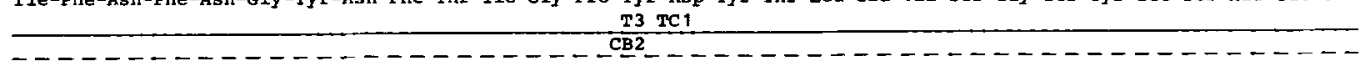

300

310

Pro-Ket-Asp-Phe-Pro-GIu-Pro-Val-Gly-Pro-Leu-Ala-Ile-VaI-Gly-Asp-Ala-Phe-Leu-Arg-Lys-Tyr-Tyr-Ser-Ile-Tyr-Asp-Leu-Gly- CB2 $-11 \ldots-1$ T15

320

Asn-Asn-Ala-Val-GlY-Leu-Ala-Lys-Ala-Ile

T15

$4<+1$

Figure 6. Amino acid sequence of proteinase A from Saccharomyces cerevisiae. Tryptic peptides are assigned Tn, cyanogen bromide peptides $\mathrm{CBn}$ and o-iodosobenzoic acid peptides IBAn. Peptides from hydroxylamine and cyanogen bromide cleavage of tryptic peptides are assigned NGTn and CBTn, respectively. Solid lines indicate sequenced sections of peptides, dashed lines indicate non-sequenced sections. Arrows indicate residues determined by $\mathrm{C}$-terminal digestion. $\mathrm{CHO}$ indicates $\mathrm{N}$-linked carbohydrate. The residues are numbered continuously. 
ing of pepsin (43), which is also used in the following.

Proteinase A shows $46 \%$ sequence identity with porcine cathepsin D, $40 \%$ with porcine pepsin and $38 \%$ with human renin. The homology with cathepsin D is increased to $63 \%$ if conservative replacements among acid, basic, hydrophobic and hydroxy-amino acids are disregarded. Proteinase A and bovine chymosin, which are immunologically related (see Figure 2 ), show $37 \%$ sequence identity. The sequence homology with penicillopepsin and endothiapepsin (38) is $25 \%$ and $26 \%$, respectively. It is striking, that the enzyme with closest homology with proteinase $A$, cathepsin $D$, is the only other intracellular enzyme on the list, suggesting that specific functional requirements on intracellular aspartic proteinases restrict possibilities for structural diversifications. The amino acid sequence of proteinase A does not, however, include the four-residue insertions found in cathepsin D at positions 91A-91D and 280A$280 \mathrm{D}$, which have been proposed to have a processing function for the lysosomal enzyme (11). Cleavage occurs in the insertion 91A-91D in porcine cathepsin $D$ during conversion from the one-chain to two-chain form of the enzyme (44). The gene sequence of human cathepsin D also reveals an insertion in position $91 \mathrm{~A}-91 \mathrm{~K}$ (12) and mouse submandibulary renin is cleaved in an insertion 280A-280D (36). The significance of this proteolytic processing in cathepsin D and renin is not established, and there is no evidence for a corresponding two-chain form of the intravacuolar yeast proteinase $A$.

In position 159 a three residue insertion (in reference to pepsin) was necessary. This insertion occurs in a position corresponding to a beta-hairpin loop, from residue 157-159, in the penicillopepsin, endothiapepsin and pepsin structure. Similar insertions occur at position 159 in mouse submandibulary renin (one residue), cathepsin D (two residues) and human renin (four residues). It was furthermore necessary to introduce a deletion at position 209 , in a region where the homology between the aspartic proteinases is low.

One of the three disulphide bridges in mammalian aspartic proteinases, Cys206-Cys210, is lacking in proteinase $\mathrm{A}$, which in this regard resembles the fungal aspartic proteinases. The other halfcystines in proteinase A are in conserved positions, suggesting conservation of the disulfide bridges Cys45-Cys50 and Cys250Cys283, found in pepsin (43) etc. These two disulfide bridges are also retained in an aspartic proteinase from Mucor miehei (1), while endothiapepsin and penicillopepsin possess only cystine (Cys250-Cys283) $(22,38)$.

In aspartic proteinases from Endothia parasitica and Penicillium janthinellum $(23,37)$ the two catalytically essential aspartic acid residues, Asp32 and Asp215, are arranged in a symmetrical hydrogen bonded network involving Asp32, Thr33, Gly34, Ser35 and Asp215, Thr216, Gly 217 and Thr218. The conservation of these residues in proteinase $\mathrm{A}$, as well as in all other sequenced aspartic proteinases, strongly suggests a common catalytic mechanism and active site structure of these enzymes. Asp304, which is hydrogen bonded to the peptide oxygen of Thr 216 in the fungal proteinases, is also conserved, like Tyr75 in the flap region, which projects above the active site. JAMES and SIELECKI (23) have emphasized a hydrophobic patch in the penicillopepsin binding cleft, adjacent to Asp32 and Asp215, which might be essential for interactions with the hydrophobic residues in substrates cleaved by aspartic proteinases $(6,8)$. The corresponding residues in proteinase A comprise Tyr275, Ile284, Leu220, Thr222, Gly297, Leu299, Ile301, Ala213, Tyr189, and Ile128, which also are predominantly hydrophobic.

Another structural relationship between proteinase $A$ and e.g. pepsin, is the remarkable conservation of hydrophobic residues corresponding to the molecular core $(22,45,47)$. These residues are in positions $4,6,14,18,20$, 27,29,31,38-42,45,56,71,73,80,84,89,91,94,101, $119-125,137,145,151-155,165,170,175,179$, $194,197,199,212-214,221,223,228,232,236$, $238,246,248,250,256,259,261,268,270,275$, $277,283,292,300,307,311,314$, and 321-324. The conservation of glycines in positions 21 , $34,76,78,82,92,119,122,168,217,237,297,303$, and 322 indicates a common structural restriction on the size of the side chain in these positions, which are predominantly at beta-hairpin loops in the structure of e.g. penicillopepsin. 
In contrast to this, the distribution of charged residues in proteinase $\mathrm{A}$ differs considerably from the distribution in other aspartic proteinases. Glu81, Asp93, Asp100, Asp126, Arg150, Glu172, Asp 178, Arg185, Glu191, Asp201, Arg253, and Glu294 correspond to uncharged residues in other aspartic proteinases. Residues Ala60, Tyr138, and Leu316 are hydrophobic like in penicillopepsin, while residues in these positions are charged in all mammalian aspartic proteinases. Such alterations in the charge distribution might influence substrate binding, and hence the specificity of proteinase A relative to the other aspartic proteinases.

The high number of paired or tripled basic residues in proteinase A $(149-150,185-187$, 239-240 and 308-309) is remarkable, and in this respect proteinase $A$ resembles human renin, which also possesses four such combinations (239-242, 280D-281, 308-309, and 316-317).

There are two glycosylated asparagines in proteinase A. One is in position 67 , which is also glycosylated in cathepsin $\mathrm{D}$ and human renin $(21,44)$, the other is in position 267 , which is a glycosylation site thus far unique to proteinase A. Both residues correspond to surface regions on penicillopepsin, where the two sites are facing away from the active site. The role of the carbohydrate moiety is not well established. In mammalian cells the glycosylation of lysosomal hydrolases has been shown to direct the transport from the Golgi body to the lysosomes (18), but results of experiments with yeast treated to inhibit glycosylation with tunicamycin, indicate that this targeting mechanism is not essential in yeast (42). Furthermore, correct processing of the precursor of proteinase $A$ is apparently independent of glycosylation (34). However, the conservation of glycosylation site 67 in intracellular aspartic proteinases from species as distantly related as an unicellular yeast and mammals, suggests a critical role of this carbohydrate moiety.

The occurrence of 3 peaks containing glycosylated tryptic peptide $\mathrm{T} 1$ after ion-exchange (Figure 5), and 3-4 close bands of proteinase $A$ on the isoelectric focusing gel between $\mathrm{pH} 4.0$ and 4.1 might be explained from possible inhomogeneity of the carbohydrate moiety.

The aspartic proteinase isolated from Saccha- romyces carlsbergensis did not reveal significant differences from proteinase $A$ with respect to molecular weight, isoelectric point, proteolytic activity and stability, and the identical 40 amino acid $\mathrm{N}$-terminal sequences and complete immunological cross-reactivity, suggest that these enzymes have similar structures.

\section{ACKNOWLEDGEMENTS}

The authors wish to acknowledge Mss. SIDSEL EHLERS and Mr. THORKILD BEENFELD for excellent technical assistence with preparation and characterization of enzymes and peptides, and Mss. Lone Sørensen, Pia BREDdAM, and BODIL CORNELIUSSEN for the amino acid analysis and sequencing. Cand.scient. LARS PETER JEPSEN is thanked for performing immune blotting assays.

\section{REFERENCES}

1. BeCH, A. -M. \& B. Foltmann: Partial primary structure of Mucor miehei protease. Neth. Milk Dairy J. 35, 275-280 (1981)

2. BJERRUM, O. J., K. P. LARSEN \& M. WilkeN: Some recent developments of the electroimmunochemical analysis of membrane proteins. In: Modern Methods in Protein Chemistry, Tschesche, H. Ed., Walter de Gruyter, Berlin, New York 79-124 (1983)

3. Bornstein, P. \& G. Balian: Cleavage at Asn-Gly bonds with hydroxylamine. Meth. Enzymol. 47, 132-145 (1977)

4. Dixon, H. B. F. \& R. N. Perham: Reversible blocking of amino groups with citraconic anhydride. Biochem. J. 109, 312-314 (1968)

5. Dreyer, T., K. Biedermann \& M. Ottesen: Yeast proteinase in beer. Carlsberg Res. Commun. 48, 249-253 (1983)

6. Dreyer, T., I. Svendenen \& M. Ottesen: Partial primary structure and substrate specificity of proteinase A from Saccharomyces cerevisiae. Biochem. Soc. Transac. 13, 1142-1143 (1985)

7. Dubois, M., K. A. Gilles, J. K. Hamilton, P. A. ReBERS \& F. SMITH: Colorimetric method for determination of sugar and related substances. Anal. Chem. 28, 350-356 (1956)

8. Dunn, B. M., B. Kammermann \& K. R. MCCURRY: The synthesis, purification and evaluation of a chromophoric substrate for pepsin and other aspartyl proteases. Anal. Biochem. 138, 6873 (1984) 
9. EDMAN, P.\& A. BEGG: A protein sequenator. Eur. J. Biochem. 1, 80-91 (1967)

10. EDELHOCH, H.: Spectroscopic determination of tryptophan and tyrosin in proteins. Biochemistry 6, 1948-1954 (1967)

11. Erickson, A. H., G. E. Conner \& G. Blobel: Biosynthesis of a lysosomal enzyme. J. Biol. Chem. 256, 11224-11231 (1981)

12. Faust, P. L., S. Kornfeld \& J. M. Chirgwin: Cloning and sequence analysis of cDNA for human cathepsin D. Proc. Natl. Acad. Sci. USA 82, 4910-4914 (1985)

13. Foltmann, B., V. B. Pedersen, H. Jacobsen, D. KaUfFMAN \& G. WYBRaNDT: The complete amino acid sequence of prochymosin. Proc. Nat. Acad. Sci. USA 74, 2321-2324 (1977)

14. Friedman, M., J. C. Zahnley \& J. R. Wagner: Estimation of the disulfide content of trypsin inhibitors as $\mathrm{S}$ - $\beta$-(2-pyridylethyl)-L-cysteine. Anal. Biochem. 106, 27-34 (1980)

15. GRahaM, R. J, JR., U. Lundholm \& M. J. KaRNOVSKY: Cytochemical demonstration of peroxidase activity with 3-amino-9-ethyl-carbazole. J. Histochem. Cytochem. 13, 150-153 (1965)

16. HAPNER, K. D. \& P. E. WILCOX: Fragmentation of bovine chymotrypsinogen $\mathrm{A}$ and chymotrypsin $A \alpha$. Specific cleavage at arginine and methionine residues and separation of peptides including $\mathbf{B}$ and $\mathrm{C}$ chains of chymotrypsin. Biochemistry 9, $4470-4480$ (1970)

17. HARBOE, N. \& A. INGILD: Immunization, isolation of immunoglobulins, estimation of antibody titre. In: A Manual of Quantitative Immunoelectrophoresis. Methods and Applications, eds. : Axelsen, N. H., J. Krøll \& B. Weeke. Universitetsforlaget, Oslo, pp. 161-164 (1973)

18. Hasilik, A \& E Neufeld: Biosynthesis of lysosomal enzymes in fibroblasts: Phosphorylation of mannose residues. J. Biol. Chem. 255, 4946-4950 (1980)

19. Hata, T., R. Hayashi \& E. Doi: Purification of yeast proteinases I. Fractionation and some properties of these proteinases. Agr. Biol. Chem. 31, $150-159$ (1967)

20. HiRS, C. H. W.: Determination of cystine as cysteic acid. Methods Enzymol. 11, 59-62 (1967)

21. Hobart, P. M., M. Fogliano, B. A. O'Connor, I. M. SChaEFer \& J. M. ChirgwiN: Human renin gene: Structure and sequence analysis. Proc. Nat. Acad. Sci. USA 81, 5026-5030 (1984)

22. Hsu, I. -N., L. T. J. Dalbaere, M. N. G. James \& T. Hofmann: Penicillopepsin from Penicillium janthinellum. Crystal structure at $2.8 \dot{A}$ and sequence homology with porcine pepsin. Nature $266,140-$ 145 (1977)
23. JAMES, M. N. G. \& A. R. SiElecki: Stereochemical analysis of peptide bond hydrolysis catalyzed by the aspartic proteinase penicillopepsin. Biochemistry 24, 3701-3713 (1985)

24. Johansen, J. T., K. BReddam \& M. Ottesen: Isolation of carboxypeptidase $\mathrm{Y}$ by affinity chromatography. Carlsberg Res. Commun. 41, 1-14 (1976)

25. Johansen, J. T., C. Overballe-Petersen, B. Martin, V. HasemanN \& I. SvendSEN: The complete amino acid sequence of copper, zinc superoxide dismutase from Saccharomyces cerevisiae. Carlsberg Res. Commun. 44, 201-217 (1979)

26. JONES, E. W.: Genetic approaches to the study of protease function and proteolysis in Saccharomyces cerevisiae. In: Yeast Genetics, Fundamental and Applied Aspects, Spencer, J. F. T., D. M. Spencer \& A. R. W. Smith Eds., Springer Verlag, New York 167-203 (1983)

27. KELleR, H. P., F. ERNi, H. R. LiNDER \& R. W. FreI: Dynamic slurry-packing technique for liquid chromatography columns. Anal. Chem. 49, 1958-1963 (1977)

28. KRøLL, J.: Tandem crossed immunoelectrophoresis. In: Handbook of Immunoprecipitation-ingel-techniques, Axelsen, N. H. Ed., Blackwell, pp. 135-139 (1983)

29. LAEMMLI, U. K. Cleavage of structural proteins during the assembly of the head of bacteriophag T4. Nature 227, 324-331 (1980)

30. Lenney, J. F. \& J. M. Dalbec: Purification and properties of two proteinases from Saccharomyces cerevisiae. Arch. Biochem. Biophys. 120, 42-48 (1967)

31. Lenney, J. F., P. MAtile, A. Wiemken, M. SchelLENBERG \& J. MEYER: Activities and cellular localization of yeast proteases and their inhibitors. Biochem. Biophys. Res. Commun. 60, 1378-1383 (1974)

32. LUNDBLAD, R. L. \& W. H.STEIN: On the reaction of diazoacetyl compounds with pepsin. J. Biol. Chem. 244, 154-160 (1969)

33. Mahoney, W. C., P. K. Smith \& M. A. HermodSON: Fragmentation of proteins with o-iodosobenzoic acid and a reactive contaminant that modify tyrosyl residues. Biochemistry 20, 443-448 (1981)

34. Mechler, B., M. Müller, F. Meussdoerffer \& D. H. WOLF: In vivo biosynthesis of the vacuolar proteinases A and B in the yeast Saccharomyces cerevisiae. J. Biol. Chem. 257, 11203 -11206(1982)

35. Meussdoerffer, F., P. TORTORA \& H. Holzer: Purification and properties of proteinase A from yeast. J. Biol. Chem. 255, 12087-12093 (1980)

36. Misono, K.S., J. -J. Chang \& T. Inagami: Amino acid sequence of mouse submaxillary gland renin. 
Proc. Natl. Acad. Sci. USA 79, 4858-4862 (1982)

37. Pearl. L. \& T. Blundell: The active site of aspartic proteinases. FEBS Lett. 174, 96-101 (1984)

38. Pedersen. V. B.: (Personal communication)

39. SAHEKI, T. \& H. Holzer: Comparisons of the tryptophan synthase inactivating enzymes with proteinases from yeast. Eur. J. Biochem. 42, 621$626(1974)$

40. Saheki, T. \& H. Holzer: Proteolytic activities in yeast. Biochim. Biophys. Acta 384, 203-214 (1975)

41. SAlKowSKI, E.: Ueber Zuckerbildung und andere Fermentationen in der Hefe. Z. Phys. Chem. 13, 506-538 (1889)

42. Schwaiger, H., A. Hasilik, K. von Figura, A. WIEMKEN \& W. TANNER: Carbohydrate-free carboxypeptidase $\mathrm{Y}$ is transferred into the lysosomelike yeast vacuole. Biochem. Biophys. Res. Commun. 104, 950-956 (1982)

43. Sepulveda,P., J.Marciniszyn, D. Liu \& J. Tang: Primary structure of porcine pepsin. J. Biol. Chem. $250,5082-5088$ (1975)

44. Shewale, J.G. \& J. TanG: Amino acid sequence of porcine spleen cathepsin D. Proc. Nat. Acad. Sci. USA 81, 3703-3707 (1984)

45. Sibanda, B. L.. T. Blundell, P. M. Hobart, M. Fogliano, J. S. Bindra, B. W. Dominy \& J. M. CHIRGWIN: Computer graphics modelling of human renin. FEBS Lett. 174, 102-111 (1984)
46. STevens, T. H.: (Personal communication)

47. Subramanian, E., I. D. A. Swan, M. Liu, D. R. Davies, J. A. Jenkins, I. J. Tickle \& T. L. Blun. DELL: Homology among acid proteases: Comparison of crystal structures at $3 \AA$ resolution of acid proteases from Rhizopus chinensis and Endothia parasitica. Proc. Natl. Acad. Sci. USA 74, 556-559 (1977)

48. Svendsen, I., B. Martin \& I. Jonassen: Characteristics of hiproly barley III. Amino acid sequence of two-lysine rich proteins. Carlsberg Res. Commun. 45, 79-85 (1980)

49. TANG, J.: Specific and irreversible inactivation of pepsin by substrate like epoxides. J. Biol. Chem. 246, 4510-4517 (1971)

50. Towbin, H., T. Staehelin \& J. Gordon: Electrophoretic transfer of proteins from polyacrylamide gels to nitrocellulose sheets: Procedure and some applications. Proc. Natl. Acad. Sci. USA 76, 43504354 (1979)

51. Wolf, D. H. \& H. Holzer: Proteolysis in yeast. In: Microorganisms and Nitrogen Sources, Payne, J. W. Ed., John Wiley and Sons Ltd., 431-458 (1980)

52. WOOlFord, C. A., L. B. Daniels, F. J. Park, E.W. JONES, J. V. ARSDELl \& M. A. INNIS: Vacuolar hydrolase muturase of Saccharomyces cerevisiae is an aspartyl protease encoded by the PEP4 gene. (in preparation) 


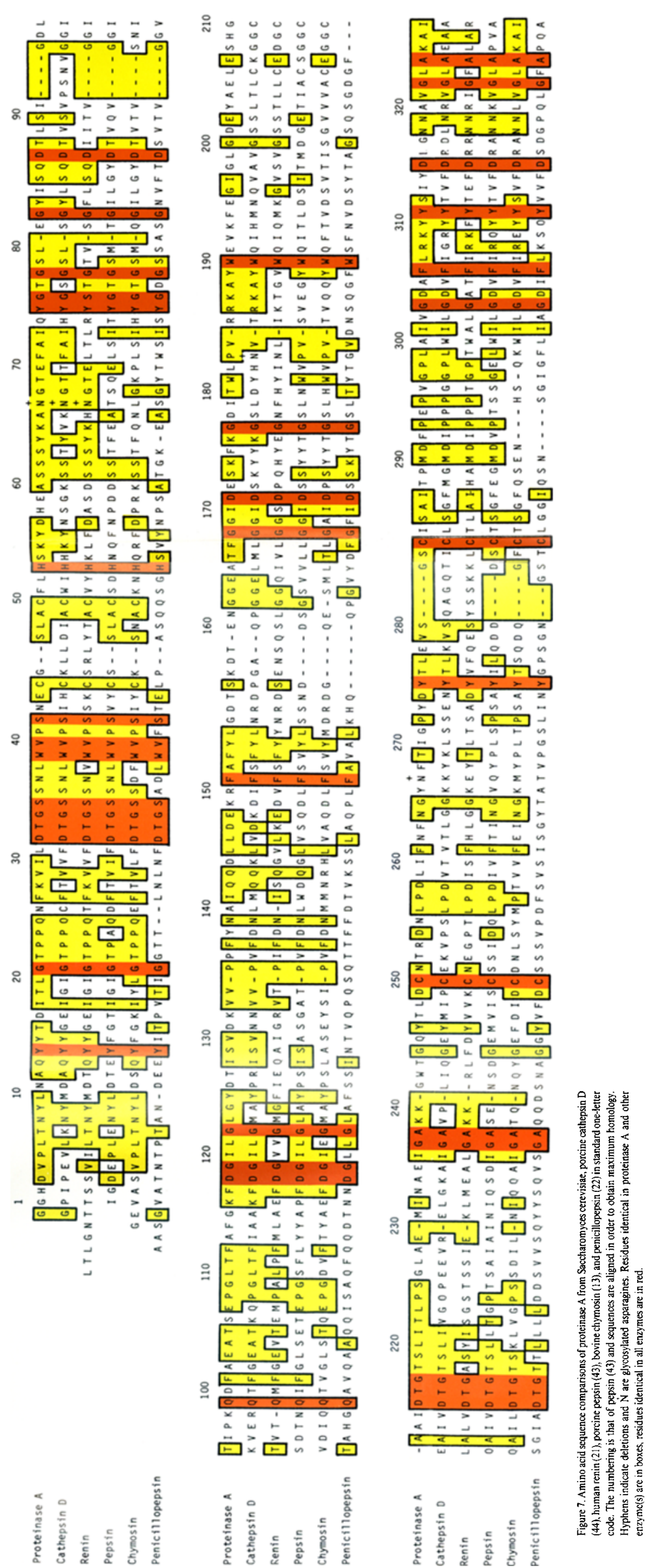

